kan berøves udefra eller forrådes indefra, hvor individet kobler sin samvittighed fra og lader sig trælbinde af den kollektive bevidstheds ufrihed.

I spørgsmålet om at fastholde sin originale identitet under det ydre pres fra en massiv socialisation, som både er magtfuld og »sat i system«, har dialogen mellem de to tænkere făet fornyet relevans, ikke blot for individer, men for hele folkeslag, hvis identitet og livsrum trues af nutidens formynderiske systemkolonisering. Bertelsens bog er god for danskere at have med ind i det kommende Europa!

\title{
En tilfældig slægt
}

\section{Af Hellmut Toftdahl}

Birgit Michelsen: Kateketen, provsten og socialisten. Tre slagtleds historie. Forlaget Anis. Arhus 1989. 236 sider. 225 kr. Nu nedsat til 78 kr.

At skrive slægtshistorie, således at det private og personlige bliver til en brik i datidens kulturelle og politiske puslespil, er en kunst. Når det lykkes, føres læseren tilbage i tid og oplever datidens strømninger gennem dokumenter, der sammenflettes til en nærværende livsverden. Den lille fortælling om en tilfældig slægt bliver da en lødig vikar for den store fortælling om fortiden, der ikke længere fortælles. I disse postmoderne tider, hvor fortiden udstykkes i fragmenter, er der en egen tryghed forbundet med at blive inviteret indenfor hos en familie, hvis aner på godt og ondt gennemlevede en omskiftelig epokes tilskikkelser som alvorlige eksistentielle anliggender.

Det sker, når man læser Birgit Michelsens beretning om sin slægts historie. Man oplever en 3 dages sejltur over Kattegat fra Aarhus til København, berettet af bogens hovedperson, den rastløse, fascinerende Christian, der senere ender sine dage i Leipzig som socialist og »naturaliseret Tydsker «. Han var ellers søn af en pligtforkyndende fader, der »forviist « som provst i Thisted, reflekterede 1840ernes radikale kristendomsanfægtelser, - en »Kjæmpe i Speculation« over det kristne dilemma mellem tro som personlig sandhed og tro på den objektive sandhed.

Man oplever en ankomst med tog til Københavns Hovedbanegård, fortalt af den samme Christian i et romanfragment, der vidner om digterisk talent for den virkelighed, der $\mathrm{i}$ disse år mere og mere udfordrede digtningens skønmaleri.

Anerne trækkes også til Christians bedstefar, kateketen Hans Chr., der deltog i opgøret med Grundtvigs »Kirkens Gienmæle« på H.N. Clausens side. Han var modstander af såvel den moraliserende pligtkristendom som de »Gudelige Forsamlinger « af vakte, hvortil han også regnede Grundtvig.

Kontroverserne omkring Grundtvig og Søren Kierkegaard opleves her af nogle personer, for hvem kristendommen var et dybt personligt anliggende. 
Deres kriser afspejler den krise, som den kristne forkyndelse gennemgik i disse år. Flere andre personer, sønner og døtre af de tre, møder vi også i bogen. Deres anfægtelser og opgør, spændende fra radikalt fritænkeri til engagement $i$ den tyske socialisme flettes af Birgit Michelsen sammen til en levende fremstilling af tidens alsidige bevidsthedshistorie.

I slutkapitlet knytter hun an til Dostojevskijs roman »Ynglingen«. Her berettes der ligeledes om en »tilfældig « familie. Ordet »tilfældig « betyder ikke »ligegyldigt hvilken «, men »underkastet tilfældighed «, dvs. »uden sammenhæng og mening «. Dostojevskij har i romanen gjort denne families skæbne til et spejl af den almindelige samfundsudvikling $\mathrm{i}$ Rusland $\mathrm{i}$ forrige århundrede og dens opløsende tendenser. Birgit Michelsen har i sin rodløse ane, socialisten Christian, set et eksistentielt grundvilkår, som rummer et perspektiv også for "vor tids rodløse mennesker «: »i sin afvisning af kristendomnıen uden at vide ordentlig besked med, hvad det er han afviser, ligner han mange rettænkende moderne mennesker «. Hans afvisning af virkelighedsforfalskninger ser hun som et håb for vor tid, »hvor vi lever blandt lokkende eller skræmmende vrængbilleder af sandt menneskeliv«.

Og heri har hun nok ret. I sin rastløse tvivl på de "sandheder «, han havde fået $\mathrm{i}$ arv fra sin præstefamilie, og i sin jagt efter »den rette tænkning « var Christian forud for sin tid. I sin redelighed og behov for at komme til rette med sig selv, havde han sikkert mere til fælles med såvel Grundtvig som Søren Kierkegaard, end han selv var klar over. Det er tankevækkende, at de, herhjemme, tænkte ret i deres opgør med abstraktionens »rette tænkning «, mens han søgte og fandt »den rette tænkning « $i$ en art frivillig landflygtighed som »naturaliseret Tydsker «. Som den tyske idealisme har han identificeret tænkning med væren, abstraktion med virkelighed. Den socialistiske utopisme blev hans brækjern mod den religiøse familietradition, han var på flugt fra. Hans oprør og de dønninger, det sendte ind i.familien, har lighedspunkter med det Sideniuskompleks, Henrik Pontoppidan senere beskrev i "Lykke-Per «, omend Lykke-Per valgte en anden flugtvej end eksilet og ideologien.

Christians oprør er interessant i grundtvigsk sammenhæng, fordi man her ser et vidnesbyrd om, hvilke kirkepolitiske og eksistentielle kræfter Søren Kierkegaard og Grundtvig med deres frigørende teologi var oppe imod blandt repræsentanterne for den bestående kristenhed. 